\title{
超急性期静注血栓溶解療法の普及
}

豊田一則*

\section{Prevalence of intravenous thrombolysis for hyperacute ischemic stroke}

\author{
Kazunori TOYODA
}

要約 : 脳梗塞超急性期の静注血栓溶解療法は, 病的血栓を遺伝子組み換え組織型プラスミノゲン・アクティベー 夕の力で溶解して, 血栓で詰まった脳動脈を再開通させ，脳の組織が決定的に傷む前に十分な脳への血流を戻 す治療である，発症後 4.5 時間以内に治療開始可能な患者に適応があるが，最近の知見に基づき，発症時刻不 明の患者でも頭部画像診断の異なる撮像法による虚血所見出現具合の差 (DWI-FLAIR ミスマッチ所見) やペナ ンブラ所見を確認できれば治療を行えるようになった. 国内施行率は脳梗塞発症者の 1 割前後と推測されるが, 治療対象となるべき患者はこれょり遥かに多く，更なる治療の普及が必要である，アルテプラーゼが世界で承 認された唯一の血栓溶解薬であるが，近年血栓への親和性が高いテネクテプラーゼを用いた臨床試験が海外で 多く行われ，オフラベルで使用を始めた地域も増えた．国内でも同薬の早期導入が望まれる.

Key words: acute ischemic stroke, thrombolysis, tissue-type plasminogen activator, alteplase, tenecteplase

\section{はじめに}

急性期脳梗塞への治療手段としての遺伝子組み換 え組織型プラスミノゲン・アクティベータ (recombinant tissue-type plasminogen activator: rt-PA) であるアルテプラーゼを用いた静注血栓溶解療法は, 発症から 4.5 時間以内に治療可能な脳梗塞で慎重に 適応判断された患者に対して, 国内外の治療指針で 強く推奨される．同じく推奨度の高い治療である急 性期脳血管内治療としての機械的血栓回収療法とと もに, 急性期再灌流療法として脳梗塞の標準治療に 位置づけられる。しかしながら依然として改善すべ き点も多い.

ここでは, 静注血栓溶解療法の最新の話題を中心 に解説する.

\section{1. 静注血栓溶解療法の機序と効果}

脳梗塞急性期には不可逆的損傷を被った虚血巣中 心部の周囲に, 機能障害を来しているが不可逆的損 傷に至っていない虚血性ペナンブラが存在し, 発症 数時間以内に梗塞巣へ移行する. 血栓溶解薬はプラ スミノゲンをプラスミンに変換してフィブリンの分 解活性を高め, 血管内の病的血栓を溶解し得る（図 1) ${ }^{1}$. 超急性期にこのような血栓溶解薬を用いて途 絶した脳血流をごく早期に再開させ, 不可逆的障害 を回避することが, 血栓溶解療法の目的である. 不 可逆的損傷に陥った神経細胞を再生させる治療が確 立していない現在に扔いて, 超急性期の再灌流療法 がもっとも転帰改善効果の高い治療といえる.

静注血栓溶解療法の臨床化に向けて, 1990 年代初 めには日本が世界を牽引していた時期もあったが, 結局米国で開発されたアルテプラーゼのみが脳梗塞 治療用に承認され, 現在に至るまで同薬が脳梗塞患 者に公式に承認された唯一の血栓溶解薬である。日 本では諸外国に遅れて，2005年に同薬が脳梗塞へ適 応追加された. 国内多施設共同登録事業である日本 脳卒中データバンクの情報によれば，近年では脳梗 塞患者全体の 1 割強が静注血检溶解療法を受けてい
*責任者連絡先：

国立循環器病研究センター脳血管内科

干 564-8565 大阪府吹田市岸部新町 6-1

Tel: 06-6170-1070, Fax: 06-6170-2012

E-mail: toyoda@ncvc.go.jp 

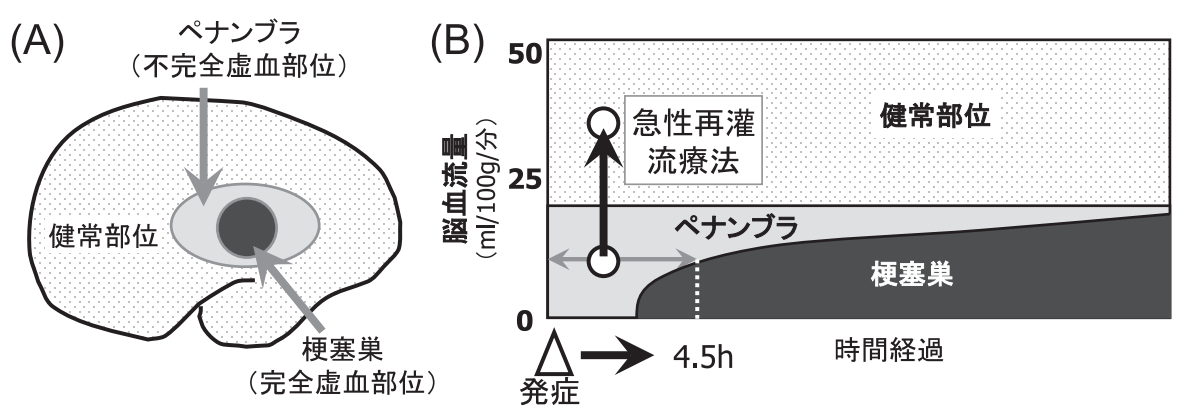

(C)

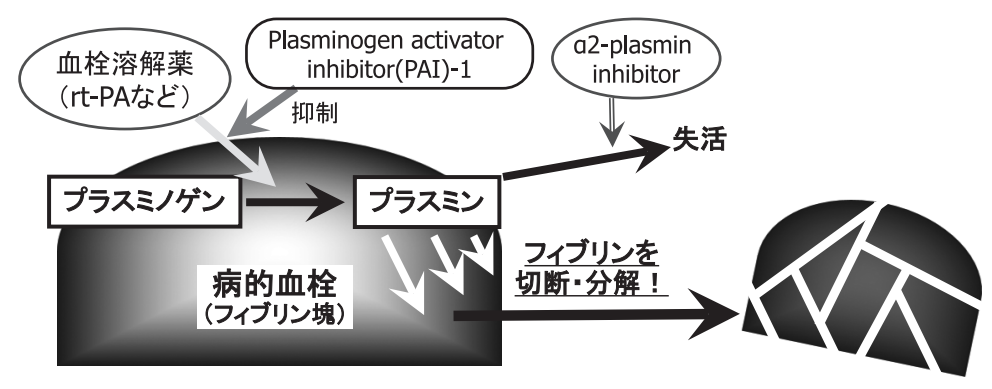

図 1 脳虚血の進行と血栓溶解療法の仕組み. 文献 1 より改変引用

$\mathrm{A}$ ：梗塞巣とペナンブラの位置関係. ペナンブラは梗塞巣と同じ血管領域の梗塞巣周辺に現れる. B : 時間経過と脳血流 量. 脳動脈閉塞により脳血流量が一定レベル以下に低下すると, 脳は機能障害（ペナンブラ）に陥り，さらに短時間に， 虚血侵襲のより強い部位から梗塞巣（完全虚血）に置き換わる. 発症後の超急性期（静注血栓溶解療法の場合は 4.5 時間以 内）に急性再灌流療法（静注血栓溶解療法ないし機械的血栓回収療法）によって閉塞動脈を再開通させ，完全虚血に到る 前に正常の脳血流量に戻せば，梗塞を回避できる．C：遺伝子組み換え組織型プラスミノゲン・アクティベータ（rt-PA） はフィブリンへの親和性が高く, 病的血栓内でフィブリンに結合したプラスミノゲンを活性化するので, 効率よく血栓を 溶かす.

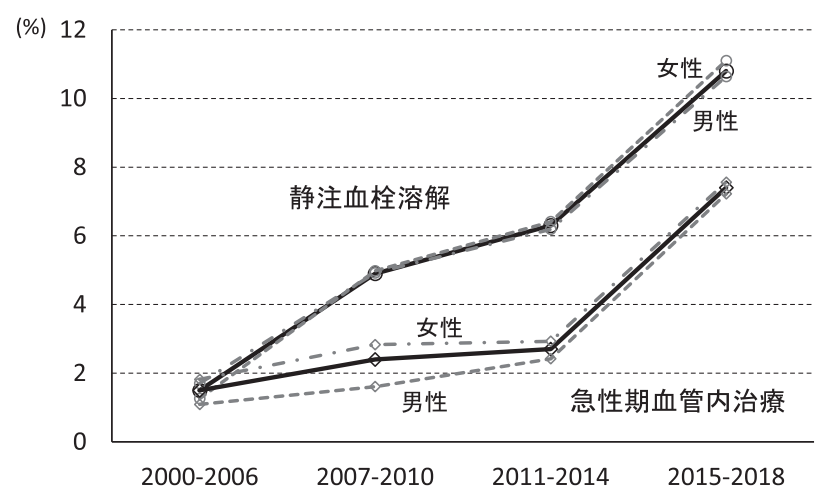

図 2 脳梗塞患者における急性期再灌流療法の施行頻度：日本脳卒中データバンク. 文献 2 よ引用 2000 年〜2018 年に登録された脳梗塞患者 125,722 例を解析対象とする.

る $(\text { 図 2 })^{2)}$ 。ただしこの情報は専門性の高い施設を 中心としたものであり, 薬剤の出荷量などから推測 するに, 2018 年時点での治療件数は約 17,000 件, 脳 梗塞全体の 7 $8 \%$ 程度で（国内での脳梗塞発生件数 もまた推測值であるが), 十分に普及した治療とはま
だ言い難い.

脳梗塞急性期治療の成績は慢性期の患者自立度で 評価されることが多く, 修正ランキン尺度 (modified Rankin Scale: mRS）が世界全体で広く用いられ，0 から 6 までの 7 段階で示される（0：無症状，1：問 


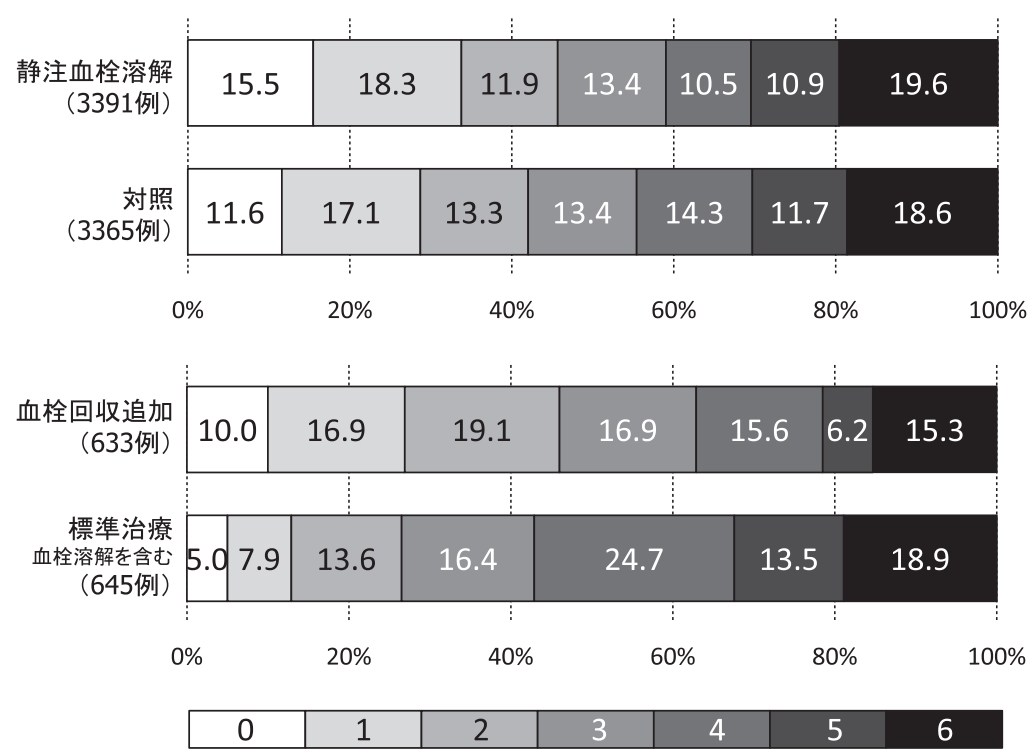

図 3 急性期再灌流療法に関する無作為化比較試験の IPD メ夕解析結果（修正ランキン尺度）。文献 4, 5 より改変引用 上段：Stroke Thrombolysis Trialists' Collaborators Group による9 試験, 6,756 例の統合解析 ${ }^{4)}$. 静注血栓溶解療法施行群と, 偽薬ないし対照治療群の比較. このうち 8 試験は発症後 3 ないし 4.5 時間以内に治療を開始し, 90 日後に評価を行ってい る. IST-3 試験（3,035 例）のみは発症後 6 時間以内に治療を開始し, 180 日後に Oxford Handicap Scale 用いて評価を行っ ている. 下段：HERMES collaboratorsによる 5 試験, 1,287 例の統合解析 ${ }^{5)}$. 静注血栓溶解療法を含めた標準治療群と, さ らに機械的血栓回収療法を追加した群の比較.90日後に評価を行っている.

題となる障害なし，2：軽度障害，3：中等度障害, 4 歩行や日常生活に介助を要する比較的高度の障害, $5:$ 高度障害でベッド上生活, 6 : 死亡)。図 3 に, 静 注血栓溶解療法および機械的血栓回収療法の無作為 化比較試験の参加者毎データの統合解析（individual participant data [IPD] メ夕解析）における治療成績を 示す. 上段は静注血栓溶解と偽薬ないし対照治療 90 日後（一部 180 日後）の mRS 值を比べている ${ }^{3,4)}$. 完全自立と考えられる 0 または 1 の割合は，静注血 栓溶解によって $5.1 \%$ 増えている. 一方下段は, 血栓 溶解を含めた標準治療に機械的血栓回収を追加する ことで，0または 1 の割合が $14 \%$ 増えており，両治 療の成果に相当の差が生じている ${ }^{5)}$ 。 ただし上段の IPD メ夕解析は, 開発初期の成功しなかった臨床試 験も全て含めており, 臨床の場で実感する静注血栓 溶解療法の効果（大雑把に 1 割強の改善が見込めそ う）を必ずしも反映していないと思える。いずれに せよ, 静注血栓溶解療法は普及率と治療効果の 2 点 で, まだ発展途上といえる。

\section{2. 静注血栓溶解療法における「時間」の問題}

虚血侵襲を受けた脳組織は時間が経過するほど二 次的な出血を起こし易くなるため, 静注血栓溶解療 法を広く普及させるうえで安全性を担保するために, 治療開始可能時間の㛜しい制限を要した。国内外で 本治療が承認された当初は発症後 3 時間以内の治療 開始が治療適応要件とされ, 欧州での ECASS-3 試験 で新知見を得た後 ${ }^{6)}$, 国内では 2012 年に発症後 4.5 時間以内まで治療開始可能と変更された。脳卒中発 症が疑われる患者が必ずしも速やかに緊急受診しな いこと, 地域によっては治療可能な施設への搬送に 時間を要すること, 脳梗塞診断, 特に頭蓋内出血と の鑑別のためには診察所見に加えて頭部画像所見が 不可欠であることなどを考え併せると，この時間制 限は本治療を普及させるうえでの大きな阻害要因と なる。 とくに, 睡眠中発症例や発症時目撃者不在の コミュニケーション障害例は正確な発症時刻が分か らず, 静注血栓溶解療法を受けられないことが多い が，このような例は脳梗塞患者全体の 2 割を占める 
(A)

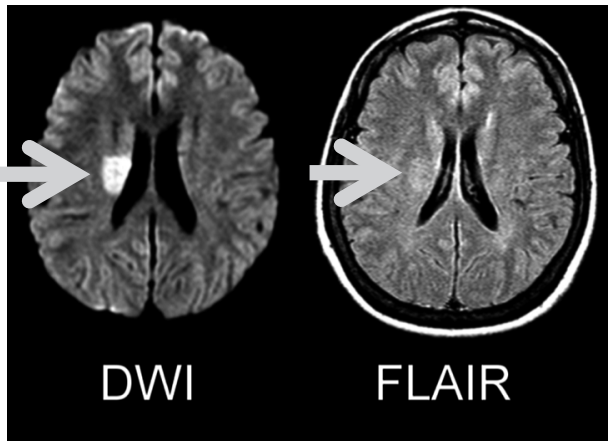

(B)

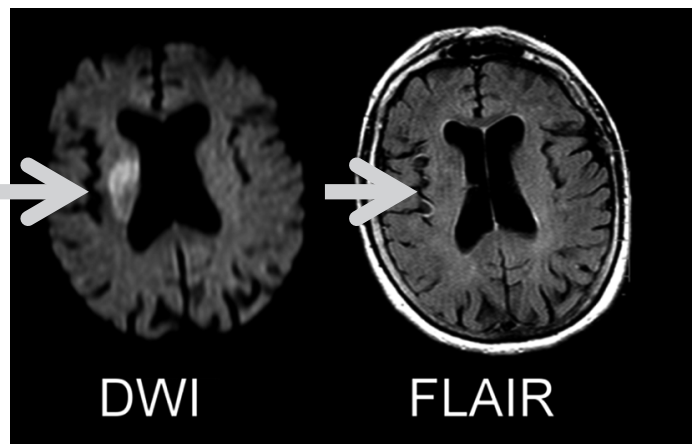

図 4 MRI 拡散強調画像（DWI）と FLAIR 画像での超急性期脳梗塞所見

（A）DWIでの陽性所見に合致した部位に，FLAIRでも陽性所見を認める。（B）DWIでの陽性所見に合致した部位に， FLAIR でも陽性所見を認めない. DWI-FLAIR ミスマッチないし FLAIR 陰性所見と称される.

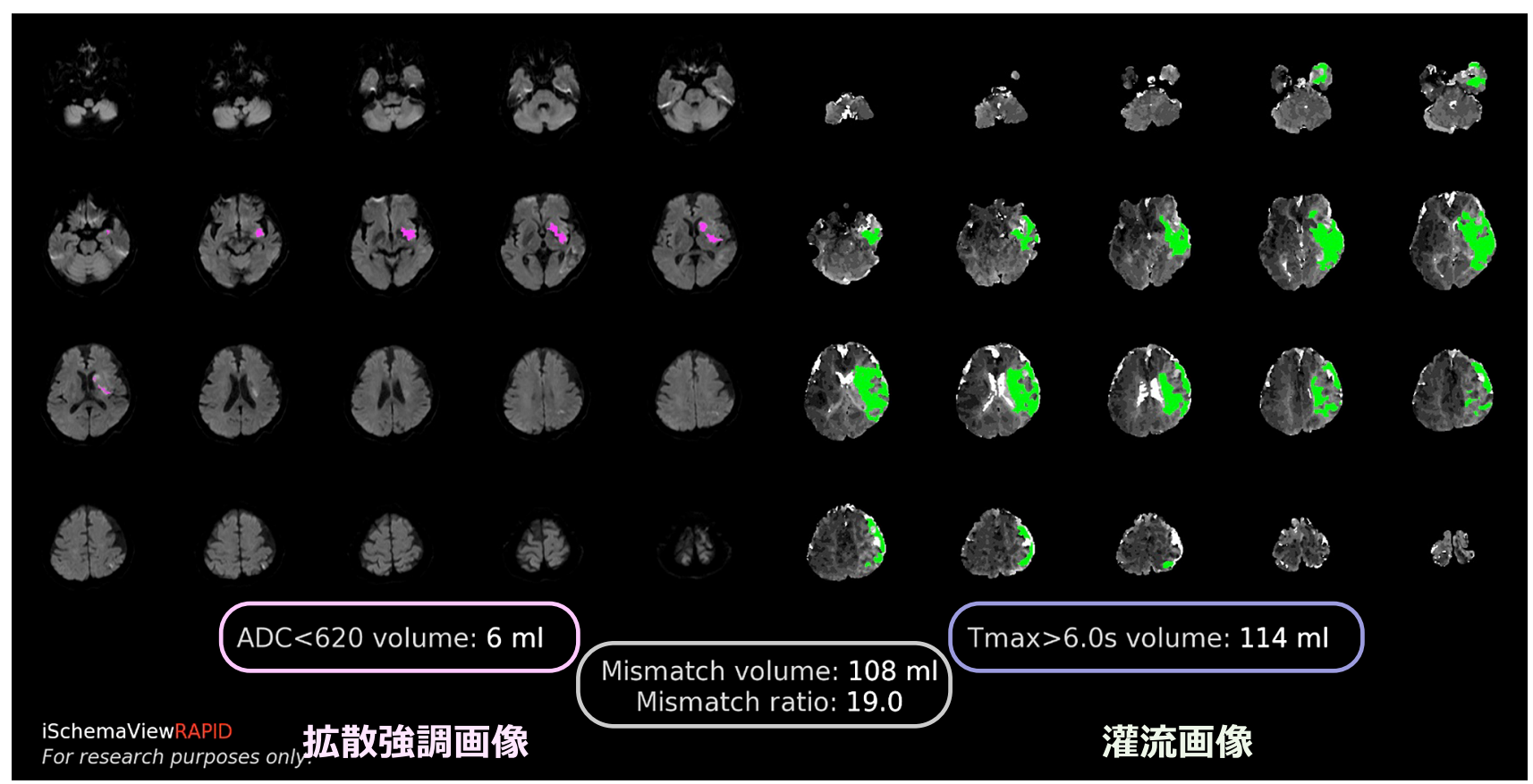

困 5 MRI 拡散強調画像（DWI） と灌流画像での超急性期脳梗塞所見. 文献 11 より引用

DWI での陽性所見は体積 $6 \mathrm{~mL}$, 灌流画像での陽性所見は $114 \mathrm{~mL}$ で, 再所見の差が $108 \mathrm{~mL}$, 比が 19.0 であることが, 示さ れている，主幹脳動脈の閉塞によって灌流が低下した部位は広域であるが，そのうち虚血に至った部位は少なく，相当の 虚血性ペナンブラが存在することが示される. 画像解析ソフトウェア RAPID ${ }^{\circledR}$ (RApid proceeding of PerfusIon and Diffusion) を用いた撮影.

と言われる.

しかしながら脳への虚血侵襲の程度は, 本来個人 差や脳梗塞機序や部位による差が大きく, 一律の時 間制限が科学的に最善の治療適応決定手段とは言い 難い. 頭部画像診断技術を駆使することで侵襲程度
や救済可能範囲を同定し, 事例ごとの治療適応の可 否を決めることが可能かもしれない.この考えに基 づき，適応拡大へのさまざまな試みがなされてきた。

MRIの各種撮像法のうち, 拡散強調画像 (diffusion weighted image: DWI）が発症後 1 時間以内の早期虚 


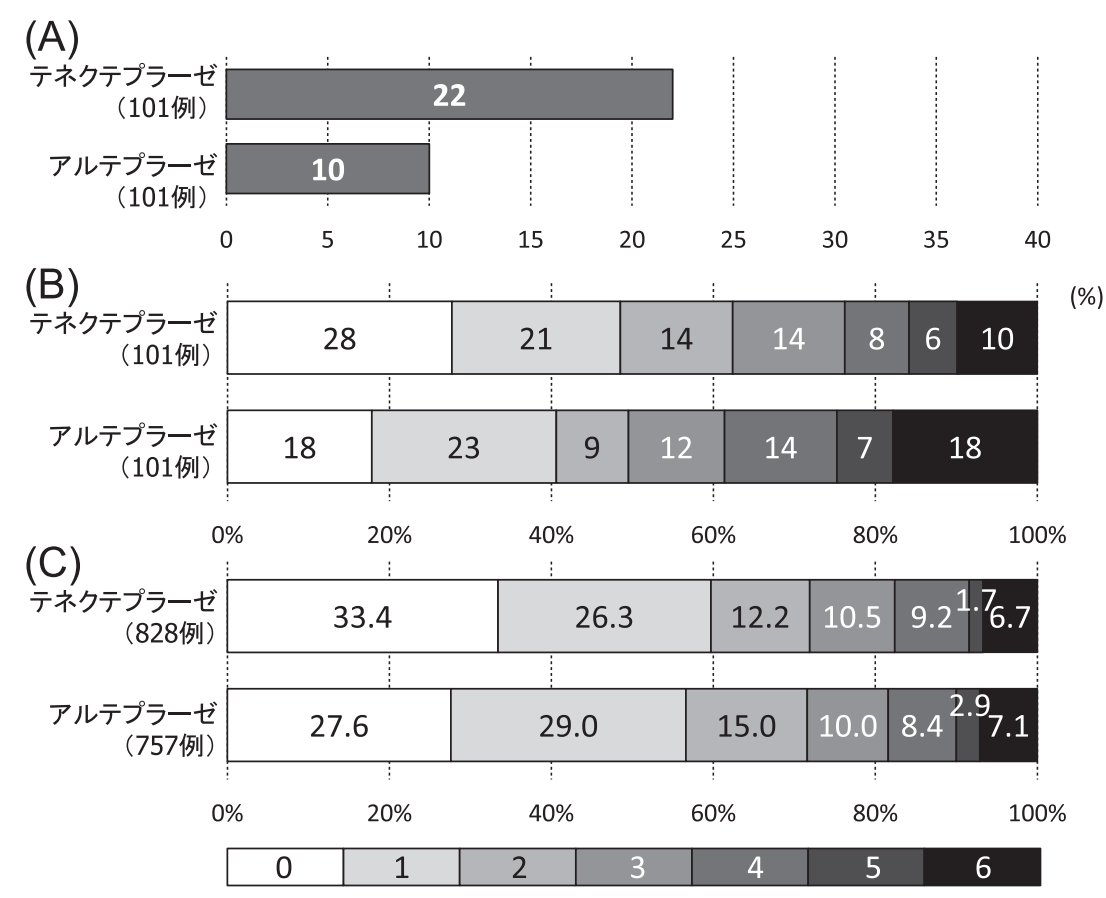

図 6 急性期脳梗塞患者に対するテネクテプラーゼとアルテプラーゼの治療効果：EXTEND-IA TNK 試験及び同試験を含め た 5 試験のメ夕解析. 文献 15,16 より改変引用

(A) EXTEND-IA TNK 試験で血栓溶解薬投与後早期に行われた初回血管造影検査での再開通率. テネクテプラーゼ群の再 開通率が非劣性（P=0.003）, 有意性（P=0.02）とも有意に勝る.（B）EXTEND-IA TNK 試験での 90 日後の修正ランキ ン尺度による機能転帰．テネクテプラーゼ群の転帰がシフト解析で有意に良好である $(\mathrm{P}=0.04)$. (C) メ夕解析での 90 日後の修正ランキン尺度による機能転帰.

血変化も描出できるのに対して, fluid-attenuated inversion recovery（FLAIR）画像は描出までに3〜6 時間程度を要す. DWI で陽性の病巣がFLAIR で描出 されていない状況（DWI-FLAIR ミスマッチ, FLAIR 陰性所見, 図 4) が発症後 4.5 時間以内を示す有用な 指標となり得ることが幾つかの観察研究で確認さ れた ${ }^{7)}$. DWI-FLAIR ミスマッチ所見をもって発症時 刻不明脳梗塞患者（発見から 4.5 時間以内）を登録 し, 静注血栓溶解療法群と偽薬ないし標準治療群に 無作為に割り付けた比較試験が国内外で行われ，こ のうち欧州を中心とした WAKE-UP 試験では静注血 栓溶解療法群の 90 日後転帰良好 (mRS 0 ないし 1$)$ 率が有意に高かった ${ }^{8)}$. 国内医師主導試験 THAWS は全体では有効性の群間差を得なかったが 9), 梗塞 巣のごく小さい例を除外して行った事後解析で, 静 注血栓溶解療法群の 90 日後転帰良好 $(\mathrm{mRS} 0 \sim 1)$ 率が有意に高かった ${ }^{10)}$ 。 また MRI や CT の灌流画像 で描出される灌流異常域と虚血コアの差を用いて,
虚血変化を呈していない可逆性の灌流異常域, いわ ゆる虚血性ペナンブラのサイズによって患者を登録 し (図 5 $)^{11)}$, 静注血栓溶解療法の効果を調べる無作 為化比較試験も, 近年報告された ${ }^{12)}$ 。これら 2 種類 の画像診断基準を用いた無作為化比較試験の IPD メ 夕解析で, 発症時刻不明脳梗塞患者への静注血栓溶 解療法の有効性が示され ${ }^{13)}$, 国内の治療指針でも DWI-FLAIR ミスマッチ所見を有する発症時刻不明 脳梗塞患者に本治療が推奨されている ${ }^{14)}$.

\section{3. 静注血栓溶解療法における「薬凨」の問題}

静注血栓溶解療法のもう一つの大きな問題点は, 国内で脳梗塞患者に使える血栓溶解薬がアルテプ ラーゼのみであり, 薬剤が更新されていない点であ る. アルテプラーゼの血栓溶解効果や血管再開通率 は高くなく, また総量の $10 \%$ を急速静注後, 残量を 1 時間かけて持続静注するよう定められているため, 
投与方法が煩雑である. 多くの新規血栓溶解薬が臨 床の場で試され，アルテプラーゼを超える有効性を 示せずに来た．近年, 新たな候補薬としてテネクテ プラーゼが注目される. テネクテプラーゼは遺伝子 組み換え技術によってアルテプラーゼ分子 296〜299 番目のアミノ酸（リジン, ヒスチジン, アルギニン) をアラニンに置き換え生成された薬剤である，フィ ブリン特異性を高め, 半減期はアルテプラーゼより 6 倍長く (20〜24分), プラスミノゲンからプラスミ ンへの活性化を阻害する plasminogen activator inhibitor(PAI) -1への抵抗性も高いため, 静注単回投 与で十分な血栓溶解作用を発揮する.

テネクテプラーゼは海外で急性心筋梗塞の治療薬 として承認されている。豪州を中心に行われた EXTEND-IA TNK 試験は, 主幹脳動脈閉塞を認め機 械的血栓回収療法を企図する発症 4.5 時間以内の脳 梗塞患者を, テネクテプラーゼ群とアルテプラーゼ 群に無作為に割り付け, 投与後早期に行われた初回 血管造影検査での再開通率, 90 日後の $\mathrm{mRS}$ を用い た転帰良好率ともにテネクテプラーゼ群が有意に高 いことを示した (図6A，B ${ }^{15)}$. EXTEND-IA TNK 試 験を含めた 5 試験のメ夕解析で, 90 日後の転帰良好 率（mRS 0～1） はテネクテプラーゼ群が $57.9 \%$ で, アルテプラーゼ群（55.4\%）に対する非劣性が示さ れた $(\text { 図 6C })^{16)}$. 最新の豪州および米国のガイドラ インでは, 脳梗塞患者への血栓溶解薬としてアルテ プラーゼとテネクテプラーゼが併記され推奨されて いる. 最近欧米でオフラベルでの使用が増え, 需要 過多に伴い, 同じ企業が同じ生産ラインで時期を替 えて製造しているアルテプラーゼが，今後製造縮小 ないし中止されることも懸念される.

一方国内では現時点でテネクテプラーゼを取り扱 う企業がなく, 同薬の研究開発も進んでいない. 近 い将来の国内でのテネクテプラーゼ導入への道を開 くべく, 筆者らは厚生労働省や日本脳卒中学会など の支持と理解を得ながら, 特定臨床研究としてテネ クテプラーゼとアルテプラーゼの国内医師主導無作 為化比較試験を企画中である.

著者の利益相反 (COI) の開示 :

研究費 (受託研究, 共同研究, 寄付金等)（日本医療

\section{研究開発機構 [AMED])}

\section{文献}

1) 豊田一則：血栓溶解療法. 日内会誌 98: 1263-1269, 2009.

2) 国循脳卒中データバンク 2021 編集委員会: 脳卒中データ バンク 2021, 東京, 中山書店, 2021.

3) Emberson J, Lees KR, Lyden P, Blackwell L, Albers G, Bluhmki E, Brott T, Cohen G, Davis S, Donnan G, Grotta J, Howard G, Kaste M, Koga M, von Kummer R, Lansberg M, Lindley RI, Murray G, Olivot JM, Parsons M, Tilley B, Toni D, Toyoda K, Wahlgren N, Wardlaw J, Whiteley W, del Zoppo GJ, Baigent C, Sandercock P, Hacke W; Stroke Thrombolysis Trialists' Collaborative Group: Effect of treatment delay, age, and stroke severity on the effects of intravenous thrombolysis with alteplase for acute ischaemic stroke: A meta-analysis of individual patient data from randomised trials. Lancet 384: 1929-1935, 2014.

4) Lees KR, Emberson J, Blackwell L, Bluhmki E, Davis SM, Donnan GA, Grotta JC, Kaste M, von Kummer R, Lansberg MG, Lindley RI, Lyden P, Murray GD, Sandercock PA, Toni D, Toyoda K, Wardlaw JM, Whiteley WN, Baigent C, Hacke W, Howard G; Stroke Thrombolysis Trialists' Collaborators Group: Effects of alteplase for acute stroke on the distribution of functional outcomes: A pooled analysis of 9 trials. Stroke 47: 2373-2379, 2016.

5) Goyal M, Menon BK, van Zwam WH, Dippel DW, Mitchell PJ, Demchuk AM, Dávalos A, Majoie CB, van der Lugt A, de Miquel MA, Donnan GA, Roos YB, Bonafe A, Jahan R, Diener HC, van den Berg LA, Levy EI, Berkhemer OA, Pereira VM, Rempel J, Millán M, Davis SM, Roy D, Thornton J, Román LS, Ribó M, Beumer D, Stouch B, Brown $\mathrm{S}$, Campbell BC, van Oostenbrugge RJ, Saver JL, Hill MD, Jovin TG; HERMES collaborators: Endovascular thrombectomy after large-vessel ischaemic stroke: A metaanalysis of individual patient data from five randomised trials. Lancet 387: 1723-1731, 2016.

6) Hacke W, Kaste M, Bluhmki E, Brozman M, Dávalos A, Guidetti D, Larrue V, Lees KR, Medeghri Z, Machnig T, Schneider D, von Kummer R, Wahlgren N, Toni D; ECASS Investigators: Thrombolysis with alteplase 3 to 4.5 hours after acute ischemic stroke. N Engl J Med 359: 1317-1329, 2008.

7) Aoki J, Kimura K, Iguchi Y, Shibazaki K, Sakai K, Iwanaga T: FLAIR can estimate the onset time in acute ischemic stroke patients. J Neurol Sci 293: 39-44, 2010.

8) Thomalla G, Simonsen CZ, Boutitie F, Andersen G, Berthezene Y, Cheng B, Cheripelli B, Cho TH, Fazekas F, Fiehler J, Ford I, Galinovic I, Gellissen S, Golsari A, Gregori J, Günther M, Guibernau J, Häusler KG, Hennerici M, Kemmling A, Marstrand J, Modrau B, Neeb L, Perez de la Ossa N, Puig J, Ringleb P, Roy P, Scheel E, Schonewille W, Serena J, Sunaert S, Villringer K, Wouters A, Thijs V, Ebinger $\mathrm{M}$, Endres $\mathrm{M}$, Fiebach JB, Lemmens R, Muir KW, Nighoghossian N, Pedraza S, Gerloff C; WAKE-UP Investigators: MRI-guided thrombolysis for stroke with unknown time of onset. N Engl J Med 379: 611-622, 2018.

9) Koga M, Yamamoto $H$, Inoue $M$, Asakura $K$, Aoki J, Hamasaki T, Kanzawa T, Kondo R, Ohtaki M, Itabashi R, Kamiyama K, Iwama T, Nakase T, Yakushiji Y, Igarashi S, 
Nagakane Y, Takizawa S, Okada Y, Doijiri R, Tsujino A, Ito Y, Ohnishi H, Inoue T, Takagi Y, Hasegawa Y, Shiokawa Y, Sakai N, Osaki M, Uesaka Y, Yoshimura S, Urabe T, Ueda T, Ihara M, Kitazono T, Sasaki M, Oita A, Yoshimura S, Fukuda-Doi M, Miwa K, Kimura K, Minematsu K, Toyoda K; THAWS Trial Investigators: Thrombolysis with alteplase at $0.6 \mathrm{mg} / \mathrm{kg}$ for stroke with unknown time of onset: A randomized controlled trial. Stroke 51: 1530-1538, 2020.

10) Toyoda $K$, Inoue $M$, Yoshimura $S$, Yamagami H, Sasaki M, Fukuda-Doi M, Kimura K, Asakura K, Miwa K, Kanzawa T, Ihara M, Kondo R, Shiozawa M, Ohtaki M, Kamiyama K, Itabashi R, Iwama T, Aoki J, Minematsu K, Yamamoto H, Koga M; THAWS trial investigators: Magnetic resonance imaging-guided thrombolysis $(0.6 \mathrm{mg} / \mathrm{kg})$ was beneficial for unknown onset stroke above a certain core size: THAWS RCT Substudy. Stroke 52: 12-19, 2021.

11）井上学：脳還流画像を用いた脳卒中治療の新展開. 循環 器病研究の進歩 39: 29-37, 2018.

12) Ma H, Campbell BCV, Parsons MW, Churilov L, Levi CR, Hsu C, Kleinig TJ, Wijeratne T, Curtze S, Dewey HM, Miteff F, Tsai CH, Lee JT, Phan TG, Mahant N, Sun MC, Krause M, Sturm J, Grimley R, Chen CH, Hu CJ, Wong AA, Field D, Sun Y, Barber PA, Sabet A, Jannes J, Jeng JS, Clissold B, Markus R, Lin CH, Lien LM, Bladin CF, Christensen S, Yassi N, Sharma G, Bivard A, Desmond PM, Yan B, Mitchell PJ, Thijs V, Carey L, Meretoja A, Davis SM, Donnan GA; EXTEND Investigators: Thrombolysis guided by perfusion imaging up to 9 hours after onset of stroke. N Engl J Med 380: 1795-1803, 2019.

13) Thomalla G, Boutitie F, Ma H, Koga M, Ringleb P, Schwamm LH, Wu O, Bendszus M, Bladin CF, Campbell BCV, Cheng B, Churilov L, Ebinger M, Endres M, Fiebach JB, Fukuda-
Doi M, Inoue M, Kleinig TJ, Latour LL, Lemmens R, Levi CR, Leys D, Miwa K, Molina CA, Muir KW, Nighoghossian N, Parsons MW, Pedraza S, Schellinger PD, Schwab S, Simonsen CZ, Song SS, Thijs V, Toni D, Hsu CY, Wahlgren N, Yamamoto H, Yassi N, Yoshimura S, Warach S, Hacke W, Toyoda K, Donnan GA, Davis SM, Gerloff C; Evaluation of unknown Onset Stroke thrombolysis trials (EOS) investigators: Intravenous alteplase for stroke with unknown time of onset guided by advanced imaging: Systematic review and meta-analysis of individual patient data. Lancet 396: 1574-1584, 2010.

14）日本脳卒中学会脳卒中医療向上 - 社会保険委員会／静注 血栓溶解療法指針改訂部会：静注血栓溶解（rt-PA）療 法 適正治療指針 第三版 2019 年 3 月. 脳卒中 41: 205-246, 2019.

15) Campbell BCV, Mitchell PJ, Churilov L, Yassi N, Kleinig TJ, Dowling RJ, Yan B, Bush SJ, Dewey HM, Thijs V, Scroop R, Simpson M, Brooks M, Asadi H, Wu TY, Shah DG, Wijeratne T, Ang T, Miteff F, Levi CR, Rodrigues E, Zhao H, Salvaris P, Garcia-Esperon C, Bailey P, Rice H, de Villiers L, Brown H, Redmond K, Leggett D, Fink JN, Collecutt W, Wong AA, Muller C, Coulthard A, Mitchell K, Clouston J, Mahady K, Field D, Ma H, Phan TG, Chong W, Chandra RV, Slater LA, Krause M, Harrington TJ, Faulder KC, Steinfort BS, Bladin CF, Sharma G, Desmond PM, Parsons MW, Donnan GA, Davis SM; EXTEND-IA TNK Investigators: Tenecteplase versus alteplase before thrombectomy for ischemic stroke. $\mathrm{N}$ Engl J Med 378: 1573-1582, 2018.

16) Burgos AM, Saver JL: Evidence that tenecteplase is noninferior to alteplase for acute ischemic stroke: Metaanalysis of 5 randomized trials. Stroke 50: 2156-2162, 2019. 